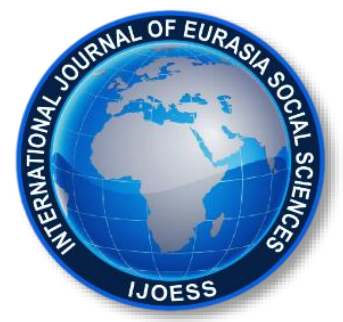

International Journal of Eurasia Social Sciences

Vol: 11, Issue: 42, pp. (1092-1114).

Article Type: Review Article

Received: 29.08.2020

Accepted: 02.12.2020

Published: 15.12 .2020

\title{
FROM BRAIN DRAIN TO BRAIN CIRCULATION: BRAIN POWER IN REGIONAL DEVELOPMENT*
}

\author{
Celal iNCE \\ Asst.Prof, Bitlis Eren University, Turkey, celalince548@gmail.com \\ ORCID: 0000-0001-6081-4100
}

\begin{abstract}
In this study, the relationships between brain drain, brain circulation and development phenomena are tried to be analyzed theoretically through various samples. One of the main problems of low-welfare societies is that people with high levels of human capital migrate to countries with high levels of welfare for many reasons. Although this form of migration brings some benefits to the source countries, it causes the further development of the target countries and offers them the main contribution. With the brain drain, the development gap between countries is getting deeper. In this context, there is usually no linear relationship between the development of the source country and the brain drain. But although brain drain is still widespread, the phenomenon of brain circulation instead of brain drain is becoming debatable within the framework of the erosion of borders and the policies developed by the source country, and there is a more optimistic view of brain circulation compared to brain drain. While brain drain causes the difference between countries to grow, according to some points of view, brain circulation can minimize this difference. When qualified programs that encourage return are accomplished, the benefits of brain circulation come to the forefront in terms of the source country. There are many programs for brain circulation between countries. While some of these programs are aimed at the mobility of the highly skilled workforce, some cover the mobility of students and staff for higher education. Intercollegiate cooperation on this issue is an important component of brain circulation. It is believed that individuals who raise their human capital through this mobility can contribute to the development of their country.
\end{abstract}

Keywords: Brain drain, development, human capital, circulation of information.

\footnotetext{
* This study was presented at the "3th International Conference on Social Sciences \& Humanities" in Turkey on 20-22 December, 2019.
} 


\section{INTRODUCTION}

Migration, in short, refers to the mobility that a person performs towards another place that will partially cover a certain period of time, relatively far from the place where he lives for various reasons. The brain drain corresponds to the fact that the individuals involved in this activity are rich in human capital with a high level of education in terms of personal characteristics. When immigrants are classified according to personal characteristics, the migration of people rich in human capital from a place where they live to another relatively remote place due to conflict, lack of opportunities and other reasons is described as a brain drain within the types of migration (Kana, 2009: 8).

These individuals are graduates of Higher Education, who have come a long way in their profession, are specialized, have a high potential for innovation and research motivation, are ahead in terms of intelligence and capacity. Those who have these characteristics and who lack the ground to realize their potential, seeking a field of application for the skills and abilities of those who have turned towards various states and societies dates back to a very long time. In history, some states and societies have been attractions for those whose characteristics are considered above because of their importance to science, art and craft. However, when it comes to the present day, when knowledge begins to be seen as the main source of power and development, especially after World War II, with the spread of globalization and the development of technology, there was a substantial increase in brain drain.

The brain drain from peripheral countries to developed central countries slows down the development of peripheral countries and contributes to the further development of developed countries (Sagırlı, 2006: I) In this context, a better standard of living and quality of life in different places around the world, higher salaries, access to advanced technology and more stable political conditions in search of high-skilled labor movement constitutes a source of concern in terms of its negative impact on the source country (Dodani \& LaPorte, 2005: 487). Especially, the fact that a significant number of those who emigrate for higher education do not return to their home country after graduation whips up this concern (Shin \& Moon, 2018).

Brain drain generally occurs in two contexts. First, a significant number of people who go abroad to study do not return to their country after their education is finished, and the other is that people with high levels of human capital migrate to other countries to have better wages and opportunities. This situation is discussed as a phenomenon that interferes with the development of developing countries (Kana, 2009: 8) Some studies focus on the positive impact of brain drain on the source country, while other studies focus on brain drain leads to a decrease in human capital, which contributes to the development of the source country's economy, and thus the growth rate of per capita income in the source country slows down (Le, 2008: 618). Some studies conducted support this claim. For example, a study of 227 scientists of Turkish origin living in the United States shows that these people mainly contribute to the development of the United States (Arslan, 2016). It is considered unfair from the point of view of the source country that people invested in the framework of 
educational activities in order to increase the level of human capital migrate to other countries and mainly contribute to the development and progression of the country in which they emigrate (Robertson, 2006: 1).

One of the main dynamics of brain drain is the conditions of the source country, and the other is the policies that the target countries have implemented to attract people with high levels of human capital to their countries. Because many governments are aware that the accumulation of human capital is very important in the development of the country and develop policies towards it (Daugeliene \& Marcinkeviciene, 2009). This policy is not new, but is constantly repeated in the historical process. During colonial times, rich countries that carried out the slave trade to meet the need for Labor entered into a rapid development process in World War II, and tried to meet this need with the signing of international agreements. However, with the advancement of technology, the decline in the need for unqualified Labor has led to a change in the migration policy of these countries (Ince, 2019). With this new era of globalization, on the one hand, the borders on information, money and capital have been lifted, and on the other hand, almost all the doors have been closed to unqualified labor migrants. Developed countries continue to produce various policies to attract people rich in human capital due to the need for a highly skilled workforce. Some of these policies are to attract the most successful students in the world, to provide various facilities for people with high human capital to enter the country and to improve their living conditions (Pazarcık, 2010).

The race to attract the brains that will create innovation and produce new ideas between countries continues rapidly (Robertson, 2006: 1). Individuals with a high level of human development are the stars sought by universities, research centers as Robertson stated (Robertson, 2006: 3). For example, immigrants from many different countries such as China, Taiwan, India, the United Kingdom, Iran, Vietnam, the Philippines, Canada and Israel constitute a significant part of the qualified workforce of Silicon Valley which is one of the leading centers of technology production in the world (Saxenian, 2002).

Migration and development continue to be discussed in the relevant literature as two different phenomena that affect, feed each other and can be the cause and consequence of each other. One of the main focus points in the discussions on the relationship between migration and development is on whether international migration negatively affects the development of the source country or contributes to its development. Although this relationship is questioned over the movement of the unskilled population, it is mainly discussed in the context of the movement of the skilled labor force. In this context, concepts such as brain drain, migration cycle and brain circulation are the focus of the discussion. Globalization, information flow and digitalization and increased population circulation contribute to keeping this debate alive.

\section{METHOD}

This study, which addresses the relationship between brain drain, brain circulation and development, is based on a literature review. A descriptive analysis was carried out by accessing scientific sources on the subject. In the study, the relationship between brain drain and development is examined and the contribution of brain circulation, which has recently been started to be used instead of brain drain, to the development process from 
the point of view of the source country, is questioned. In this context, the subject was systematically discussed through migration and development, brain circulation and development themes and a number of brain circulation applications. In this way, it was examined how the optimistic view placed on the brain circulation, which contains two way mobility instead of one-way mobility, is handled in different sources. Permission was not obtained from the ethics commission for this study because it is not a research article.

\section{Migration and Development Relationship}

Although development has various dimensions, such as social and economic, but these dimensions also have different parameters. Development means an increase in the level of social welfare, as well as economic growth in general. In this context, development, together with the increase in gross national product per capita, also means an increase in the level of education of its individuals, improvement of health conditions, and technological progress. Natural resources, physical capital, and human capital are important components of development. Human capital, which constitutes the human dimension of development, refers to a labor force of a high standard of quality. In this context, natural resources and economic capital can only lead to development when they interact with human capital (Arslan, 2016, Ince, 2015). From this point of view, the existence of human capital and migration constitute of the discussion. A recent study shows that even the migration of unskilled workers contributes greatly to the development of Western European countries.

The "guest" workforce, which was invited by the rapidly developing Western European countries to their countries with bilateral agreements right after the Second World War, played an active role in the rapid development of these countries. Transfers and remittances sent by migrants to the source country in migrations from developing peripheral countries to developed central countries have often been discussed in academic texts, where international migration can also play an important role in the development of the source country. In some of these studies on the relationship between migration and development, a positive correlation between migration and development was established periodically. However, in later studies, the positive effects of migration in terms of development, as well as its negative effects, were discussed, and the positive relationship established between migration and development was approached more cautiously In other words, today there are still concerns about whether remittances of migrants sent to source countries will be an important component of development. For example, immigrants going abroad from Turkey, Armenia and Mexico, and the fact that the currencies they send do not offer very important advantages in the development process can be evaluated in this context. In particular, the type of migration and the personal characteristics of migrants are decisive in establishing a relationship between the political, economic and social conditions of the source country (Gokbayrak, 2008: 65; Dawson, 2007).

Dependency and structuralist theory are the leading forms of explanation when a negative relationship is established between migration and development from the point of view of the source country. From this point of view, international migration is mainly due to the development difference between regions. Labor mobility in favor of capital leads to a deeper difference between regions and countries. Brain drain is also seen as a 
phenomenon that ensures the continuation of underdevelopment, such as the movement of unskilled labor, and feeds the vicious circle (Aktas, 2014: 38). Because brain drain causes a decrease in the productivity and income levels of the countries experiencing this loss and the return of public education investments (Aktas, 2014: 42). In this context, according to the traditional approach, brain drain creates a negative effect on the economy of the source country, as it causes loss of both human capital and resources spent for their education (Kasnauskiene \& Budvytyte, 2013: 740).

While doubts remain about whether the brain drain will benefit the development of the source country, economic parameters promoted by the dynamics of globalization are encouraging an increase in the brain drain. When the subject is evaluated in the context of higher education, as stated by Rebortson (2006: 3), foreign students, on the one hand, create a source of income for the educational institution, on the other hand, these people specialized in technology, engineering and other fields are valued for their contribution to the development of innovation, new ideas and patents. In other words, immigrants with a high level of human capital are valued as much as they produce and create qualified change in the countries they migrate to.

Studies claiming that immigration will have a positive impact on the development of the source country focus on the remittances made by immigrants to the source country, returns and diaspora activities, acting with such an assumption (Aktas, 2014: 38) . Brain drain becomes even more important in terms of the relationship between migration and development, where these elements that will ensure development are evaluated in the context of a qualified workforce. On the other hand, information and information-based technologies continue to become a source of power, and in this context, developed countries compete with each other to attract qualified labor to their countries (Gokbayrak, 2008: 67). The continuation of the race to attract the best brains from around the world to produce ideas that will lead to innovation and profit among countries ensures that the debate on brain drain remains dynamic (Robertson, 2006). Dynamics such as the decrease in the production capacity with migration, the non-return of public expenditures made by the state for the education of immigrants, the unfair distribution of remittances sent by immigrants, and the motivating role of the remittances to migrate the remaining ones also ensure the continuation of the discussions on the relationship between migration and development (Dawson, 2007: 9). On the other hand, in today's world, increasing bidirectional movements between countries and a number of developed programs make brain circulation more debatable, rather than brain drain.

Brain circulation is seen by some authors as a necessary phenomenon to strengthen the existence of many various factors that increase the country's economic growth, competitiveness and likewise promote the country's socio-economic and socio-cultural progress (Daugeliene \& Marcinkeviciene, 2009). 


\section{Brain circulation and development}

Information constitutes one of the important sources of regional development in the globalized world, and international bi-directional human mobility, in other words brain circulation, is one of the main elements of access to information.

As the world globalizes, barriers to international mobility of highly skilled individuals are decreasing. More and more highly skilled people tend to migrate for the purpose of studying or working abroad (Kasnauskiene \& Budvytyte, 2013: 740). This trend indirectly or directly affects the development of both the target and the source country. Transfers made by immigrants to the source country and transfers of Information, investment and technology made by immigrants to their home countries in the destination country or with returns are among the topics discussed (Gokbayrak, 2008: 69). However, as mentioned earlier, it continues to be argued that the brain drain, described as the transfer of highly skilled labor to other countries, does not contribute radically to the development of the source country, although it provides economic benefits to the migrant, it has recently been suggested that instead of this phenomenon, brain circulation may contribute more to the source country (Kasnauskiene \& Budvytyte, 2013: 740).

According to Le (2008), when people migrate to another country, they maintain their close relationship with the source country either through various mechanisms or by organizing visits from time to time. This situation allows the knowledge acquired by the employees in the target country to contribute to the productivity increase in their own countries. This constitutes a brain circulation model rather than a brain drain.

As brain circulation expresses the mobility of highly skilled workforce between the two centers (Chen, 2008), he puts forward the argument that people can actively use the knowledge and skills they have acquired in their workplace or in the institution where they are working after they go abroad and stay temporarily in order to ensure local development in returning to their country (Chen, 2008). Dawson, 2007: 2) and he emphasizes that by transferring the knowledge and skills of immigrants to their own countries, it will create brain circulation and increase the level of human capital (Aktas, 2014: 43). Rosenzweig (2008) also states that brain circulation is a phenomenon that can benefit everyone.

The importance of brain circulation for the development of the source country has become increasingly prominent in recent years and brain circulation replaces brain drain, highlighting by many studies that it is a vital process for the development of countries ' economies. Governments are not only trying to attract highly skilled workforce, but also create programs and initiatives to attract foreign research and thus improve the country's economy and competitiveness (Daugeliene \& Marcinkeviciene, 2009).

According to Batalova et al., (2017: 30), there are three basic dynamics that promote brain circulation. These are increased awareness of the role and importance of foreign professionals, the signing of mutual recognition agreements between countries, and the development of educational infrastructure. Winters (2008) states that 
one of the most important contrasts between developed and developing countries is the availability and use of highly skilled workforce. In this context, according to him, universities constitute the center of highly skilled workforce and a significant part of the brain circulation is realized through universities. Saxenian explains in his study that there is a positive relationship between higher education, brain circulation and development of the source country through the following sample:

\begin{abstract}
"Taiwanese immigrant Miin Wu, for example, arrived in the United States in the early 1970s to pursue graduate training in electrical engineering. After earning a doctorate from Stanford University in 1976, Wu saw little use for his new skills in economically backward Taiwan and chose to remain in the United States. He worked for more than a decade in senior positions at Silicon Valley-based semiconductor companies including Siliconix and Intel. He also gained entrepreneurial experience as one of the founding members of VLSI Technology. By the late 1980s, Taiwan's economy had improved dramatically, and Wu decided to return. In 1989 he started one of Taiwan's first semiconductor companies, Macronix Co., in the Hsinchu Sciencebased Industrial Park. Wu also became an active participant in Silicon Valley's Monte Jade Science and Technology Association, which was building business links between the technical communities in Silicon Valley and Taiwan" (Saxenian, 2002).
\end{abstract}

Higher education creates one of the main dynamics of migration and brain migration or brain circulation begins with this process, and the example given above shows that brain circulation begins with such a process. Because many different countries of the world do not have higher education opportunities or are very low, people migrate to other countries to achieve this goal. However, according to Dodani and Laporte (2005), a significant number of students who have completed their higher education and postgraduate studies by emigrating for this purpose do not return to the source country. According to these authors, at least half of foreign-born graduate students in France, the United Kingdom and the United States continue their lives in these countries after completing their education. According to Rosenzweig (2008)., the salaries to be received by the students studying abroad are determinant in their return to their countries.

According to a study of 2,323 foreign doctoral students in the United States, $48 \%$ of respondents want to stay in the United States after graduation, while only $12 \%$ think to return. The remaining people are those who are undecided about whether to return to their country (Shin \& Moon, 2018). As can be seen from these studies, while education is an important component of development, the probability that those who emigrate to other countries for education will not return to their own country is quite strong. With a number of brain circulation programs, this need can be met and people can return to their country after graduation. In other words, brain drain can be transformed into brain circulation, making it an important component in the development of the source country, and there is also some evidence of this (Kone \& Ozden, 2017: iii).

An empirical study conducted by Le (2010) between 1998 and 2005 through a data set of 76 developing countries provides positive evidence that the flow of international students leads to R\&D spreads in high- 
wealthy countries are directed towards low-wealth countries. Jiang et al. (2010) a study conducted using data from 1986-2005 shows that direct information distributed from G-7 countries has a positive impact on the Chinese economy, and direct information dissemination through staff flow is one of the important components of International R \& D dissemination in China.

According to some studies, as in the case of Miin $\mathrm{Wu}$, high-skilled migrants who migrate may return when conditions in their country begin to improve, although they do not want to return to their country in the first process. According to Wahba (2014), who discussed this issue closely, although many people consider the population movement as a one-way action, it is two-sided and dynamic. In addition, according to him, there is evidence that high-skilled migrants return after a certain period of time, and it is found that there is an increase in the number of returnees. This development, which can be described as brain circulation, provides an advantage because the transfer of financial and human capital to the source country contributes to the development of the source country. However, there are some precedents for the emergence of this contribution. Some of these premises depend on the immigrant's improvement in knowledge, skills and savings, while others relate to the right political options for the source country to reduce bureaucracy, have knowledge of investment opportunities, etc. It is assumed that it will more effectively facilitate brain circulation, reduce brain drain and raise human capital in the short and medium term, both regionally and nationally (Batalova et al., 2017: 3).

Along with monetary initiatives, non-monetary initiatives are also encouraged by organizations that work on the development of source countries. In this context, the knowledge and experience of immigrants together with returns play an important role in development encourages the issue to be discussed in the context of brain circulation (Gokbayrak, 2008: 69). While brain drain occurs mostly thanks to the brain circulation that contributes to the development of the target country, high-skilled migration is predicted to benefit both the target country and the source country. (Saxenian, 2002). It is predicted that global mobility of highly skilled individuals is not as negative as brain drain. It is believed that human capital of individuals will increase through brain circulation, and networks established abroad will encourage cooperation between two or more countries. (Kasnauskiene \& Budvytyte, 2013: 740).

While discussions are shifting from brain drain to brain circulation, according to some studies, there are not enough findings that brain circulation plays an important role in the development of the source country. (Dawson, 2007). Some studies show that the brain circulation theory does not express a general condition and has a limited scope of application (Chen, 2008). However, brain circulation can be expressed as offering a more optimistic picture compared to the anxiety about brain drain (Batalova et al., 2017: ix).

However, it is expected that brain circulation will gradually increase due to factors such as globalization, the removal of certain limits on human mobility, dual citizenship and the desire to make a career (Daugeliene \& Marcinkeviciene, 2009). 


\section{Some Brain Circulation Applications}

It is widely believed that brain drain creates various problems in the context of development, especially from the point of view of the source country. One of the main mechanisms used effectively in addition to the reverse brain drain and brain gain related to the reduction of the negative effects of brain drain is the programs carried out to ensure brain circulation and information circulation. Within the scope of such programs, having limitedterm employment contracts in terms of the sending country while sending individuals abroad facilitates the return and brain circulation of immigrants, as well as determining the rights and obligations of service providers and buyers (Dawson, 2007: 14). According to Daugeliene and Marcinkeviciene (2009), some Asian countries such as India, Korea and Taiwan are the leading countries that are the source of brain drain. However, these countries have recently managed to overcome the damages of brain drain thanks to successful programs for brain circulation.

On the other hand, many programs such as Marie Curie and Erasmus Mundus are being implemented for brain acquisition and brain circulation (Robertson, 2006: 3). Marie Sklodowska Curie International Scholarship and Research Mobility Grants is a program that promotes human capital mobility in quality and quantity, strengthening human potential in research and technology, supporting the career development of researchers, International and intersectoral. The Erasmus program, conducted by the European Union, also allows undergraduate, graduate and doctoral students to study between countries, allowing faculty members to conduct research at universities in different countries.

One of the brain circulation practices is the implementation of agreements between some countries aimed at removing limits on high-skilled labor mobility. One of these programs is the agreement signed between the 10 member states of the Association of Southeast Asian Nations (ASEAN) on the mobility of certain professions in order to facilitate the passage of skilled labour across borders in the Southeast Asian region. The main objective of this agreement is to promote skilled labor mobility within the region. Changing population structure, rising education level and desire, economic demands are the basis of this incentive (Batalova et al., 2017: vii). Many brain circulation programs are also being implemented in Turkey. One of the actors who organized these programs is TUBITAK. In this context, TÜBITAK takes an active role in Turkey and organizes various workshops and programs. "Research Destination Turkey " study is one of them (Arslan, 2016: 155).

\section{CONCLUSION and DISCUSSION}

Although the findings of various studies show that migration has a positive impact on development, some studies indicate that brain migration, in particular, has a negative impact on the economy of the source country (Le, 2008: 618). Moreover, the migration of highly skilled people is considered a threat to a country (Kasnauskienè \& Budvytyte, 2013). Some other studies suggest that cyclical migration, rather than mainly permanent migration, is more decisive on development. It is also stated that it provides brain gain to the country that is the source of migration. In addition, according to the point of view that immigration has a 
positive impact on development, immigrants become decisive on development by transferring their knowledge and skills to their country when they return to their country (Aktas, 2015: 38). The idea of having higher wages along with migration to other countries contributes to the accumulation of human capital, affecting the economic development of the source country. In this case, migration is thought to be effective in the accumulation of human capital (Drinkwater et al., 2003: 18).

The idea that imposes a positive meaning on migration in terms of development predicts that migrants will transfer their human capital to their country and create brain circulation (Aktas, 2015). Dynamics such as globalization, dual citizenship, and reduction of barriers to human mobility encourage two-way population mobility (Daugeliene \& Marcinkeviciene, 2009). As more and more people tend to migrate to work or study abroad, according to Kasnauskiene and Budvytyte, instead of brain drain, brain circulation becomes a more commonly used concept, and it is predicted that brain circulation will offer more benefits to the source country. Because the network established abroad and the experience provided are effective in the development of the region in returns (Kasnauskiene \& Budvytyte, 2013). The mobility of the highly skilled workforce and the brain circulation corresponding to the transfer of knowledge are gaining more acceptance in terms of development. It is estimated that having the opportunity to apply the knowledge and skills acquired abroad when they return to their country will positively affect staying (Beine, Docquier \& Rapoport, 2008). With the brain circulation, the two-way flow of skills, capital and technology becomes possible. As a result, people with high human capital who leave their country for a better life reverse the brain drain and turn it into brain circulation (Zhang, 2013).However, according to some studies, the return of immigrants to their country always means that they will contribute positively to the development of the country. The compatibility between the skills of returning migrants and employment, as well as the social, cultural and institutional context of the country of origin, are also effective (Velema, 2012). In addition, the relationship between migration and development can be examined from a wide angle through more concrete data in the context of brain circulation. However, as international migration maintains its global agenda, it is believed that the size of brain circulation will continue to be discussed.

\section{ETHICAL TEXT}

"In this article, the spelling rules, research and publication ethics, publication principles and ethical rules stated in the journal were followed. All violations arising from this article are under the responsibility of the author."

\section{REFERENCES}

Aktas, M. T. (2015). Goc olgusu ekonomik kalkınmada itici guc olabilir mi?. Aksaray Üniversitesi Iktisadi ve Idari Bilimler Fakültesi Dergisi, 7(1), 37-48.

Arslan, N. (2016). Beyin Gocu ve Kalkınma: Türkiye’nin Kalkınmasında Türk Bilim Diaspora Aglarının Rolu. Unpublished doctoral dissertation, Istanbul University Graduate School of Social Sciences, Istanbul. 
Batalova, J., Shymonyak, A. \& Sugiyarto, G. (2017). Firing Up Regional Brain Networks: The Promise of Brain Circulation in the ASEAN Economic Community. Asian Development Bank.

Beine, M., Docquier, F. \& Rapoport, H. (2008). Brain drain and human capital formation in developing countries: winners and losers. The Economic Journal, 118(528), 631-652.

Chen, Y. C. (2008). The limits of brain circulation: Chinese returnees and technological development in Beijing. Pacific Affairs, 81(2), 195-215.

Daugeliene, R., \& Marcinkeviciene, R. (2009). Brain circulation: theoretical considerations. Engineering economics, 63(4), 49-57.

Dawson, L.R. (2008). Brain drain, brain circulation, remittances and development: Prospects for the Caribbean. Centre for International Governance Innovation.http://www.cigionline.org/publications/2007/6/braindrain-brain-circulationremittances and-development-prospects-caribbean

Dodani, S. \& LaPorte, R. E. (2005). Brain drain from developing countries: how can brain drain be converted into wisdom gain?. Journal of the Royal Society of Medicine, 98(11), 487-491.

Drinkwater, S., Levine, P., Lotti, E. \& Pearlman, J. (2003). The economic impact of migration: A survey. Hamburgisches Welt-Wirtschafts-Archiv.

Friesen, W. (2014) Diaspora, Brain Circulation and Indian Development. In: Sahoo S., Pattanaik B. (eds) Global Diasporas and Development. Springer, Yeni Delhi. https://doi.org/10.1007/978-81-322-1047-4_8

Gokbayrak, S. (2008). Uluslararası goc ve kalkınma tartısmaları: Beyin gocu uzerine bir inceleme. Ankara Universitesi SBF Dergisi, 63(3), 65-82.

Ince, C. (2015). "Beseri sermaye ve ekonomik kalkınma arasındaki iliskinin sosyolojik analizi" IV. Arap-Turk Sosyal Bilimler Kongresi (pp. 177-193), SDE Yayınları.

Jiang, R., Cai, H., Li, Y., \& Li, H. (2010). China's sustained economic growth: Do direct R\&D spillovers matter?. China \& World Economy, 18(5), 37-53.

Kana, M. A. (2009). From brain drain to brain circulation. Jos Journal of Medicine, 4(1), 8-10.

Kasnauskiene, G. \& Budvytyte, A. (2013). Economic Challenges of Brain Circulation: The Small Country Case. Mediterranean Journal of Social Sciences 4(9),740-747.

Kone, Z. L. \& Ozden, C. (2017). Brain drain, gain and circulation. Knomad Workıng Paper 19. https://www.knomad.org/sites/default/files/2017-

04/KNOMAD\%20WP19_Brain\%20Drain\%20gain\%20and\%20circulation.pdf

Le, T. (2008). 'Brain Drain'or 'Brain Circulation': Evidence From OECD's International Migration and R\&D Spillovers. Scottish Journal of Political Economy, 55(5), 618-636.

Le, T. (2010). Are student flows a significant channel of R\&D spillovers from the north to the south? Economics Letters, 107(3), 315-317.

Pazarcık, S. F. (2010). Beyin Gocu Olgusu ve Amerika Birlesik Devletleri Universitelerinde Calısan Turk Sosyal Bilimciler Uzerine Bir Arastırma. Unpublished master's thesis, Canakkale Onsekiz Mart University Graduate School of Social Sciences, Canakkale. 
Rosenzweig, M. R. (2008). Higher education and international migration in Asia: Brain circulation. In Annual World Bank conference on development economics (pp. 59-100). World Bank.

Sagırlı, M. (2006). Egitim ve Insan Kaynagı Yonunden Turk Beyin Gocu: Geri Donen Turk Akademisyenler Uzerine Alan Arastırması. Unpublished doctoral dissertation, Istanbul University Graduate School of Social Sciences, Istanbul.

Saxenian, A. (2002). Brain circulation. How high-skill immigration makes everyone better off. Brookings Review, 20(1), 28-31.

Shin, G. W. \& Moon, R. J. (2018). From Brain Drain to Brain Circulation and Linkage. Shorenstein Asia Pacific Research Center Working Paper. Stanford, CA: Stanford University. https://fsi.stanford.edu/publication/brain-drain-brain-circulation-and-linkage

Susan L. Robertson (2006) Brain drain, brain gain and brain circulation. Globalisation, Societies and Education, 4(1), 1-5. 10.1080/14767720600554908

Velema, T. A. (2012). The contingent nature of brain gain and brain circulation: their foreign context and the impact of return scientists on the scientific community in their country of origin. Scientometrics, 93(3), 893-913.

Wahba, J. (2014). Who benefits from return migration to developing countries? IZA World of Labor, February, 123. 10.15185/izawol.123

Winters, L. A. (2008). Skilled labor and the international economy: Whence it comes, whither it goes. In Annual World Bank conference on development economics (pp. 15-24). World Bank.

Zhang, W. (2013). Reaping the benefits of brain circulation: the impact of the overseas study and the returnees on the development of the management education in China. In Innovation in Business Education in Emerging Markets (pp. 208-221). Palgrave Macmillan, London. 


\title{
BEYIN GÖÇÜNDEN BEYIN DOLAŞIMINA: BÖLGESEL KALKINMADA BEYIN GÜCÜ
}

\begin{abstract}
öz
Bu çalışmada beyin göçü, beyin dolaşımı ve kalkınma olguları arasındaki ilişkiler çeşitli örneklemler üzerinden teorik olarak analiz edilmeye çalışılmaktadır. Refah düzeyi düşük toplumların temel problemlerinden biri beşerî sermaye düzeyi yüksek bireylerin birçok nedenden dolayı refah düzeyi yüksek ülkelere göç etmesidir. Bu göç biçimi kaynak ülkelere birtakım faydalar sağlasa da hedef ülkelerin daha da gelişmesine neden olmakta ve esas katkıyı onlara sunmaktadır. Beyin göçü ile ülkeler arasındaki kalkınma farkı giderek daha da derinleşmektedir. Bu bağlamda kaynak ülkenin kalkınması ile beyin göçü arasında çoğu zaman doğrusal bir ilişki kurulamamaktadır. Ancak beyin göçü hala yaygın olsa da sınırların aşınması ve kaynak ülkenin geliştirmiş olduğu politikalar çerçevesinde beyin göçü yerine beyin dolaşımı olgusu tartışılır hale gelmekte ve beyin göçü ile kıyaslandığında beyin dolaşımına yönelik daha iyimser bir bakış açısı bulunmaktadır. Beyin göçü, ülkeler arasındaki farkın büyümesine neden olurken bazı bakış açılarına göre beyin dolaşımı bu farkın minimize edilmesini sağlayabilmektedir. Geriye dönüşü teşvik eden nitelikli programlar hayata geçirildiğinde kaynak ülke açısından beyin dolaşımının faydaları daha çok ön plana çıkmaktadır. Ülkeler arasında beyin dolaşımına yönelik birçok program bulunmaktadır. Bu programların bir kısmı yüksek vasıflı işgücünün hareketliliğine yönelik iken bir kısmı ise yükseköğrenime yönelik öğrenci ve personel hareketliliğini kapsamaktadır. Bu konuda üniversiteler arası iş birliği beyin dolaşımının önemli bir bileşenini oluşturmaktadır. Bu hareketlilik aracılığıyla beşerî sermayesini yükselten bireyler ülkesinin kalkınmasına bir katkı sunabileceği düşünülmektedir.
\end{abstract}

Anahtar Kelimeler: Beyin göçü, kalkınma, beşerî sermaye, bilginin dolaşımı. 


\section{Giriş}

Göç, kısaca insanın çeşitli nedenlerden dolayı yaşadığı mekândan nispeten uzak kısmen belli bir süreyi kapsayacak başka bir mekâna doğru gerçekleştirdiği hareketliliği ifade eder. Beyin göçü ise bu faaliyete katılan bireylerin kişisel özellikler açısından eğitim düzeyi yüksek beşerî sermaye açısından zengin olmasına karşlık gelmektedir. Kişisel özelliklere göre göçmenler sınıflandııılı̆ğında beşerî sermaye açısından zengin kişilerin yaşadığı mekândan çatışma, fırsat eksikliği ve diğer nedenlere bağlı olarak nispeten uzak başka bir mekâna göç etmesi göç türleri içeresinde beyin göçü olarak tarif edilmektedir (Kana, 2009: 8). Bu kişiler yükseköğrenim mezunu, mesleğinde epey mesafe kat etmiş, uzmanlaşmış, yenilik meydana getirme potansiyeli ve araştırma motivasyonu yüksek, zekâ ve kapasite bakımından ilerde olan bireylerden oluşmaktadır. Bu özellikleri taşıyan ve sahip oldukları potansiyeli icra edebileceği zeminden yoksun olan kişilerin beceri ve yeteneklerine uygulama sahası arayanların çeşitli devletlere ve toplumlara yönelmesi oldukça eskiye dayanmaktadır.

Tarihte bazı devletler ve toplumlar bilime, sanata ve zanaata verdikleri önemden dolayı yukarıda özellikleri sayılan kişiler için birer cazibe merkezleri olmuştur. Ancak bilginin gücün ve kalkınmanın asıl kaynağı olarak görülmeye başlandığı günümüze doğru gelindiğinde özellikle II. Dünya Savaşından sonra küreselleşmenin yaygınlaşması ve teknolojinin gelişmesiyle birlikte beyin göçünde büyük bir artış meydana gelmiştir. Çevre ülkelerden gelişmiş merkez ülkelere doğru gerçekleşen beyin göçü çevre ülkelerin kalkınmasını yavaşlatırken gelişmiş ülkelerin daha da geliş̧mesine katkı sunmaktadır (Sağırlı, 2006: i). Bu bağlamda dünya çapında farkı yerlerde daha iyi yaşam standardı ve yaşam kalitesi, daha yüksek maaş, ileri teknolojiye erişim ve daha istikrarı siyasi koşullar arayışıyla gerçekleşen yüksek vasıflı işgücü hareketi kaynak ülke üzerinde bıraktığı olumsuz etki bakımından bir endişe kaynağını oluşturmaktadır (Dodani ve LaPorte, 2005: 487). Özellikle yükseköğrenim için göç edenlerin önemli bir kısmının mezuniyetten sonra kendi ülkesine dönmemesi bu endişeyi kamçılamaktadır (Shin ve Moon, 2018).

Beyin göçü genel olarak iki bağlamda gerçekleşmektedir. Birincisi, öğrenim görmek için yurt dışına giden bireylerin önemli bir kısmının öğrenimleri bittikten sonra ülkelerine dönmemesi diğeri ise beşerî sermaye düzeyi yüksek bireylerin daha iyi ücret ve imkânlara sahip olmak için başka ülkelere göç etmesidir. Bu durum gelişmekte olan ülkelerin kalkınmasını sekteye uğratan bir fenomen olarak tartışılmaktadır (Kana, 2009: 8). Bazı çalışmalar beyin göçünün kaynak ülke üzerindeki pozitif etkisine odaklanırken diğer çalışmalara göre beyin göçü, kaynak ülke ekonomisinin gelişmesine katkı sağlayan beşerî sermayenin azalmasına ve dolayısıyla kaynak ülkede kişi başına düşen gelirin büyüme hızının yavaşlamasına neden olmaktadır (Le, 2008: 618). Yapılan bazı çalışmalar bu iddiayı desteklemektedir. Örneğin ABD'de yaşayan Türkiye kökenli 227 bilim insanı üzerine yapılan bir çalışma bu kişilerin esas olarak ABD’nin kalkınmasına katkı sunduğu göstermektedir (Arslan, 2016). Beşerî sermaye düzeylerini artırmak amacıyla eğitim faaliyetleri çerçevesinde yatırım yapılan kişilerin başka ülkelere göç etmesi ve esas olarak göç ettiği ülkenin gelişmesine ve kalkınmasına katkı sunması kaynak ülke açısından bir haksızık olarak değerlendirilmektedir (Robertson, 2006: 1). 
Beyin göçünün temel dinamiklerden birini kaynak ülkenin sahip olduğu koşullar oluştururken diğeri hedef ülkelerin beşerî sermaye düzeyi yüksek kişileri ülkelerine çekmek için uygulamış olduğu politikalar gelmektedir. Çünkü birçok hükümet ülkenin kalkınmasında beşerî sermaye birikiminin oldukça önemli olduğunun farkındadırlar ve buna yönelik politika geliştirirler (Daugeliene ve Marcinkeviciene, 2009). Bu politika yeni olmayıp tarihsel süreç içerisinde sürekli tekrar etmektedir. Sömürgecilik dönemlerinde işgücü ihtiyacını karşılamak üzere köle ticaretini gerçekleştiren zengin ülkeler II. Dünya Savaşında hızlı bir kalkınma sürecine girdiklerinde ülkelerarası sözleşmelerin imzalanması ile bu ihtiyacı karşılamaya çalışmışlardır. Ancak teknolojinin ilerlemesi ile niteliksiz iş gücüne olan ihtiyacın azalması bu ülkelerin göç politikasında bir değişikliğe gitmesine neden olmuştur (İnce, 2019). Küreselleşmenin etkin olduğu bu yeni dönem ile birlikte bir taraftan bilgi, para ve sermayenin önündeki sınırlar kalkarken diğer taraftan niteliksiz işgücü göçmenlerine neredeyse bütün kapılar kapanmıştır. Gelişmiş ülkeler yüksek vasıfı işgücüne olan ihtiyaçtan dolayı beşerî sermaye açısından zengin kişileri çekmek için çeşitli politikalar üretmeye devam etmektedir. Dünyanın en başarıı öğrencilerini çekme, beşerî sermayesi yüksek kişilere ülkeye girişte ve yaşam koşullarını iyileştirmede çeşitli kolaylıkların sağlanması bu politikaların bir kısmını oluşturmaktadır (Pazarcık, 2010). Ülkeler arasında yenilik meydana getirecek ve yeni fikirler üretecek beyinleri ülkelerine çekme yarışı hızla devam etmektedir (Robertson, 2006: 1). Beşerî sermeye düzeyi yüksel kişiler, üniversiteler, araştırma merkezleri ve firmalar tarafından Robertson'un ifadesi ile aranan yıldızlar olmaktadır (Robertson, 2006: 3). Örneğin dünyada teknolojinin önde gelen üretim merkezlerinden biri olan Silikon Vadisinin nitelikli iş gücünün önemli bir kısmını Çin, Tayvan, Hindistan, İngiltere, İran, Vietnam, Filipinler, Kanada ve İsrail gibi birçok faklı ülkeden gelen göçmenler oluşturmaktadır (Saxenian, 2002).

Göç ve kalkınma birbirini etkileyen, besleyen ve birbirinin nedeni ve sonucu olabilen iki farklı olgu olarak ilgili literatürde tartışılmaya devam edilmektedir. Göç ve kalkınma ilişkisi üzerine yapılan tartışmalarda esas olarak odaklanılan noktalardan biri uluslararası göçün kaynak ülkenin kalkınmasını negatif etkileyip etkilemediği ya da kalkınmasına katkı sunup sunmadığı ile ilgilidir. Bu ilişki vasıfsız nüfus hareketi üzerinden sorgulansa da temel olarak nitelikli işgücünün hareketi bağlamında tartışılmaktadır. Bu kapsamda beyin göçü, göç döngüsü ve beyin dolaşımı gibi kavramlar tartışmanın odak noktasını oluşturmaktadır. Küreselleşme, bilgi akışı ve dijitalleşme ile artan nüfus dolaşımı bu tartışmanın canlı kalmasına katkı sunmaktadır.

\section{YÖNTEM}

Beyin göçü, beyin dolaşımı ve kalkınma arasındaki ilişkinin ele alındığı bu çalışma literatür taramasına dayanmaktadır. Konuyla ilgili bilimsel kaynaklara ulaşılarak betimsel bir analiz gerçekleştirilmiştir. Çalışmada beyin göçü ile kalkınma arasındaki ilişki hangi boyutlarıyla ele alındığı ve yakın zamanda beyin göçü yerine kullanımına başlanılan beyin dolaşımının kaynak ülke açısından kalkınma sürecine ne tür katkılar sunulduğu sorgulanmaktadır. Bu kapsamda çalışmada göç ve kalkınma, beyin dolaşımı ve kalkınma temaları ve birtakım beyin dolaşımı uygulamaları üzerinden konu sistematik olarak tartışılmıştır. Böylelikle tek yönlü hareketlilik yerine çift yönlü hareketliği barındıran beyin dolaşımına yüklenilen iyimser bakış farklı kaynaklarda nasıl ele alındığı irdelenmiştir. Çalışma literatür taramasına dayalı olduğu için etik komisyonundan izin almamıştır. 


\section{Göç ve Kalkınma İlişkisi}

Kalkınmanın sosyal ve ekonomik gibi çeşitli boyutları olmakla birlikte bu boyutların da farklı parametreleri bulunmaktadır. Kalkınma genel olarak ekonomik büyümenin yanında sosyal refah düzeyinin yükselmesi anlamına da gelmektedir. Bu bağlamda kalkınma, kişi başına düşen gayri safi milli hâsılanın artışıyla birlikte, bireylerinin eğitim düzeyinin artışı, sağlık koşullarının iyileşmesi, teknolojik ilerleme anlamına da gelmektedir. Kalkınmanın önemli bileşenlerini doğal kaynaklar, fiziksel sermaye ile birlikte beşerî sermaye oluşturmaktadır. Kalkınmanın insani boyutunu oluşturan beşerî sermaye, nitelik itibari yüksek standarttaki işgücünü ifade etmektedir. Bu bağlamda doğal kaynaklar ve ekonomik sermaye ancak beşerî sermaye ile etkileşime girdiğinde kalkınmayı meydana getirebilmektedir (Arslan, 2016, İnce, 2015). Bu açıdan beşerî sermayenin varlığı ve göçü tartışmanın merkezini oluşturmaktadır. Hatta yakın dönem incelendiğinde vasıfsız işçi göçü bile Batı Avrupa ülkelerinin kalkınmasına büyük katkı sağladığı görülmektedir.

II. Dünya Savaşın hemen akabinde çok hızlı bir biçimde kalkınan Batı Avrupa ülkeleri ikili sözleşmelerle ülkelerine davet ettiği "misafir” işgücü bu ülkelerin daha da hızlı kalkınmasında etkin rol oynamıştır. Gelişmekte olan çevre ülkelerden gelişmiş merkez ülkelere doğru gerçekleşen göçlerde göçmenlerin kaynak ülkeye göndermiş olduğu havaleler, dövizler uluslararası göçün kaynak ülkenin de kalkınmasında önemli rol oynayabileceği akademik metinlerde sıkça tartışımaya başlanmıştır. Göç ve kalkınma ilişkisi üzerine yapılan bu çalışmaların bir kısmında dönemsel olarak göç ve kalkınma arasında pozitif bir korelasyon kurulmuştur. Ancak daha sonra yapılan çalışmalarda göçün kalkınma açısından pozitif etkileri ile birlikte negatif etkileri de ele alınmış, göç ve kalkınma arasında kurulan pozitif ilişkiye daha temkinli yaklaşılmıştır. Başka bir ifade ile kaynak ülkelere gönderilen göçmen dövizlerinin kalkınmanın önemli bir bileşeni olup olmayacağı konusunda tereddütler günümüzde de devam etmektedir. Örneğin Türkiye, Ermenistan ve Meksika ülkelerinde yurt dışına giden göçmenlerin göndermiş oldukları dövizlerin kalkınma sürecinde çok önemli avantajlar sunamaması bu bağlamda değerlendirilebilmektedir. Özellikle göç tipi ve göç edenlerin kişisel özellikleri, kaynak ülkenin siyasal, ekonomik ve sosyal koşulları sözü edilen olgular arasında bir ilişkinin kurulup kurulmamasında belirleyici olmaktadır (Gökbayrak, 2008: 65; Dawson, 2007).

Kaynak ülke açısından göç ve kalkınma arasında negatif bir ilişki kurulduğunda bağımlılık ve yapısalcı teori önde gelen açıklama biçimleri olmaktadır. Bu bakış açısına göre, uluslararası göç esas olarak bölgeler arasındaki gelişmişlik farkından kaynaklanmaktadır. Sermaye lehine gerçekleşen işgücü hareketliliği bölgeler ve ülkeler arasındaki farkın daha derinleşmesine yol açmaktadır. Beyin göçü de vasıfsız işgücü hareketi gibi azgelişmişliğin devamını sağlayan ve kısır döngüyü besleyen bir olgu olarak görülmektedir (Aktaş, 2014: 38). Çünkü beyin göçü, bu kaybı yaşayan ülkelerin verimlilik ve gelir düzeyinin, kamu eğitim yatırımlarının geri dönüşünün azalmasına neden olmaktadır (Aktaş, 2014: 42). Bu bağlamda geleneksel yaklaşıma göre beyin göçü hem insan sermayesi hem de onların eğitimi için harcanan kaynak kabına yol açtığı için kaynak ülkenin ekonomisi üzerinde negatif bir etki oluşturmaktadır (Kasnauskiene ve Budvytyte, 2013: 740). 
Beyin göçünün kaynak ülkenin kalkınmasına fayda sunup sunmayacağı konusunda kuşkular devam ederken küreselleşme dinamikleri tarafından teşvik edilen ekonomik parametreler beyin göçünün artışını teşvik etmektedir. Yükseköğretim bağlamında konu değerlendirildiğinde Rebortson'un (2006: 3) belirttiği gibi yabancı öğrenciler bir taraftan eğitim kurumu için bir gelir kaynağı oluştururken diğer taraftan teknoloji, mühendislik ve diğer alanlarda uzmanlaşmış bu kişiler yenilik, yeni fikirler ve patentlerin geliştirilmesine yaptıkları katkılardan dolayı değer görmektedir. Başka bir ifade ile beşerî sermaye düzeyi yüksek göçmenler göç ettikleri ülkelerde ürettikleri ve nitelikli değişim meydana getirdiği ölçüde değer görmektedir.

Göçün kaynak ülkenin kalkınmasında pozitif bir etki oluşturacağını iddia eden çalışmalar ise göçmenlerin kaynak ülkeye yaptığı havaleler, geri dönüşler ve diaspora faaliyetlerine odaklanarak böyle bir varsayımla hareket etmektedirler (Aktaş, 2014: 38). Kalkınmayı sağlayacak bu unsurlar, nitelikli işgücü bağlamında değerlendirildiği göç ve kalkınma ilişkisi açısından beyin göçü daha da önemli hale gelmektedir. Diğer taraftan bilgi ve bilgiye dayalı üretilen teknolojilerin bir güç kaynağına dönüşmesi ve bu bağlamda gelişmiş ülkelerin nitelikli işgücünü kendi ülkelerine çekmek için birbiriyle rekabet etmesi devam etmektedir (Gökbayrak, 2008: 67). Ülkeler arasında yenilikler, kârlara yol açacak fikirler üretmek için dünyanın dört bir yanından en iyi beyinleri çekme yarışının devam etmesi, beyin göçü üzerine yapılan tartışmaların dinamik kalmasını sağlamaktadır (Robertson, 2006). Göçle birlikte üretim kapasitesinin düşmesi, devletin göç eden kişilerin eğitimine yaptığı kamu harcamalarının geri dönüşünün olmaması, göçmenlerin gönderdiği dövizlerin adil paylaşılmaması, gönderilen dövizlerin geride kalan kişileri de göç etmeye motive edici rol oynaması gibi dinamikler de göç ve kalkınma ilişkisi üzerine yapılan tartışmaların devam etmesini sağlamaktadır (Dawson, 2007: 9). Diğer taraftan günümüz dünyasında ülkeler arasında çift yönlü hareketlerin artması ve geliştirilen birtakım programlar beyin göçü yerine beyin dolaşımını daha tartışılır hale getirmektedir. Bazı yazarlar tarafından ülkenin ekonomik büyümesini, rekabet gücünü artıran ve aynı şekilde ülkenin sosyo-ekonomik ve sosyo-kültürel ilerlemesini teşvik eden birçok çeşitli faktörün varlığını güçlendirmek için beyin dolaşımını gerekli bir fenomen olarak görmektedir (Daugeliene ve Marcinkeviciene, 2009).

\section{Beyin Dolaşımı ve Kalkınma}

Küreselleşen dünyada bölgesel kalkınmanın önemli kaynaklarından birini bilgi oluşturmaktadır ve uluslararası çift yönlü insan hareketliliği, başka bir ifade ile beyin dolaşımı bilgiye erişimin temel unsurlardan birini oluşturmaktadır (Friesen, 2014). Dünya küreselleştikçe yüksek vasıflı bireylerin uluslararası hareketliliği önündeki engeller azalmaktadır. Giderek daha fazla yüksek vasıflı insan yurtdışında okumak ya da çalışma amacıyla göç etme eğilimine girmektedir (Kasnauskiene ve Budvytyte, 2013: 740). Bu eğilim dolaylı veya doğrudan hem hedef hem de kaynak ülkenin kalkınmasını etkilemektedir. Göçmenlerin kaynak ülkeye yapmış olduğu havaleler diğeri ve göçmenlerin hedef ülkede veya geri dönüşlerle kendi ülkelerine yapmış olduğu bilgi, yatırım ve teknoloji transferi tartışılan konular arasında yer almaktadır (Gökbayrak, 2008: 69). Ancak daha önce de değinildiği üzere yüksek vasıflı işgücünün başka ülkelere transferi olarak tarif edilen beyin göçünün göç eden kişiye ekonomik kazanımlar sağlasa da kaynak ülkenin kalkınmasına radikal bir katkı sunmadığı tartışılmaya 
devam ederken yakın zamanda bu olgu yerine beyin dolaşımının kaynak ülkeye daha fazla katkı sunabileceği öne sürülmektedir (Kasnauskiene ve Budvytyte, 2013: 740).

Le'ye (2008) göre günümüzde insanlar başka bir ülkeye göç ettiğinde kaynak ülkeyle bağlantısını ya çeşitli mekanizmalar aracılı̆ıııla ya da zaman zaman ziyaretler düzenleyerek sıkı ilişkilerini devam ettirmektedir. Bu durum, çalışanların hedef ülkede edinmiş olduğu bilginin kendi ülkelerindeki verimlilik artışına katkıda bulunabilmesine olanak tanımaktadır. Bu beyin göçünden ziyade bir beyin dolaşımı modelini oluşturmaktadır. Beyin dolaşımı, yüksek vasıfı işgücünün iki merkez arasındaki hareketliliğini ifade ettiği gibi (Chen, 2008) insanların yurt dışına çıkıp geçici olarak kaldıktan sonra çalıştığı iş yerinde veya faaliyette bulunduğu kurumda edinmiş olduğu bilgi ve beceriyi ülkesine geri dönüşte yerel kalkınmanın sağlanmasında aktif kullanabileceği argümanını öne sürmektedir (Dawson, 2007: 2) ve "göçmenlerin bilgi ve becerilerini kendi ülkelerine aktararak beyin dolaşımı (brain circulation) yaratacağını ve beşeri sermaye düzeyini yükselteceğini vurgulamaktadır" (Aktaş, 2014: 43). Rosenzweig (2008) de beyin dolaşımının herkese fayda sunabilen bir fenomen olduğunu belirtmektedir.

Beyin dolaşımının kaynak ülkenin kalkınması açııından önemi son yıllarda giderek daha fazla ön plana çıkmakta ve beyin dolaşımı beyin göçünün yerini alarak birçok çalışma tarafından ülkelerin ekonomisinin gelişmesi için hayati bir süreç olduğunu vurgulanmaktadır. Hükümetler sadece yüksek vasıf işgücünü çekmeye çalışmamakta yabancı araştırmaları da çekmek ve böylece ülke ekonomisini ve rekabet gücünü geliştirmek amacıyla programlar oluşturmakta ve girişimlerde bulunmaktadır (Daugeliene ve Marcinkeviciene, 2009).

Batalova vd., (2017: 30) göre beyin dolaşımını teşvik eden üç temel dinamik bulunmaktadır. Bunlar; yabancı profesyonellerin rolü ve önemi konusunda artan farkındalık, ülkeler arasında karşııklı tanıma anlaşmalarının imzalanması, eğitim alt yapısının gelişmesidir. Winters (2008) gelişmiş ve gelişmekte olan ülkeler arasındaki en önemli zıtlıklardan bir tanesi yüksek vasıflı işgücünün mevcudiyeti ve kullanımı olduğunu belirtmektedir. Bu bağlamda ona göre yüksek vasıfı işgücünün merkezini üniversiteler oluşturmakta ve beyin dolaşımının önemli bir kısmı üniversiteler aracılığıyla gerçekleşmektedir. Saxenian ise çalışmasında yüksek öğretim ve beyin dolaşımı ile kaynak ülkenin kalkınması arasında pozitif bir ilişki olduğunu şu örneklem üzerinden açıklamaktadır:

\footnotetext{
“Tayvanlı göçmen Miin Wu, elektrik mühendisliğinde lisansüstü eğitim almak için 1970’lerin başında Amerika Birleşik Devletleri'ne geldi. 1976'da Stanford Üniversitesi'nden bir doktora programını kazandıktan sonra Wu, edindiği becerileri Tayvan'a dönmesi durumunda ekonomik olarak daha az fayda sağlayacağını düşündü ve ABD'de kalmayı tercih etti. On yıldan fazla Siliconix ve Silikon Vadisi merkezli yarı iletken şirketlerde üst düzey pozisyonlarda çalıştı. Ayrıca VLSı Teknolojisinin kurucu üyelerinden biri olarak girişimcilik deneyimi kazandı. 1980'lerin sonunda, Tayvan ekonomisi önemli ölçüde iyileşti ve Wu geri dönmeye karar verdi. 1989 yılında Tayvan'ın ilk yarı iletken şirketlerinden biri olan Macronix Co.'ya Hsinchu Bilim Tabanlı Endüstri Parkı'nda başladı. Wu ayrıca Silikon Vadisi ve Tayvan'daki teknik topluluklar arasında iş bağlantıları inşa eden Silikon Vadisi'nin Monte Jade Bilim ve Teknoloji Derneği'nin aktif katılımcısı oldu" (Saxenian, 2002).
} 
Yükseköğrenim göçün temel dinamiklerinden birini oluşturarak beyin göçü ya da beyin dolaşımı bu süreçle birlikte başlamaktadır ve yukarıda verilen örnek de beyin dolaşımının böyle bir süreçle başladığını göstermektedir. Dünyanın farklı birçok ülkesinde yükseköğrenim imkânları olmadığı ya da çok düşük olduğu için insanlar bu hedefini gerçekleştirmek için başka ülkelere göç etmektedir. Ancak Dodani ve LaPorte'ye (2005) göre bu amaçla göç ederek yükseköğretim ve lisansüstü eğitimlerini tamamlayan öğrencilerin önemli bir kısmı kaynak ülkeye geri dönmemektedir. Bu yazarlara göre Fransa, İngiltere ve ABD'deki yabancı doğumlu yüksek lisans öğrencilerinin en az yarısı, eğitimlerini tamamladıktan sonra bu ülkelerde yaşamlarına devam etmektedir. Rosenzweig (2008) göre yurt dışında öğrenim gören öğrencilerin ülkelerine dönmesi konusunda alacağı ücretler belirleyici olmaktadır.

ABD'de 2.323 yabancı doktora öğrencisiyle gerçekleşen bir çalışmaya göre ankete katılanların \%48'i mezun olduktan sonra ABD'de kalmayı arzu ederken sadece \%12'si geri dönmeyi düşünmektedir. Geri kalan kişiler ise ülkesine dönüp dönmeme konusunda kararsız olan kişileri oluşturmaktadır (Shin ve Moon, 2018). Bu çalışmalardan da izlendiği üzere eğitim-öğretim kalkınmanın önemli bir bileşeni iken öğrenim için başka ülkelere göç edenlerin kendi ülkesine dönmeme olasılığı oldukça güçlü görülmektedir. Birtakım beyin dolaşımı programları ile bu ihtiyaç karşılanarak mezuniyetten sonra kişilerin ülkelerine dönmesi sağlanabilmektedir. Başka bir ifade ile beyin göçü, beyin dolaşımına dönüştürülerek kaynak ülkenin kalkınmasında önemli bir bileşen haline getirilebilir ve buna dair birtakım kanıtlar da mevcuttur (Kone ve Özden, 2017: iii). Le'nin (2010) 1998-2005 yılları arasında 76 gelişmekte olan ülkeden oluşan bir veri seti üzerinden gerçekleştirdiği ampirik çalışma, uluslararası öğrenci akışının refah düzeyi yüksek ülkelerdeki Ar-Ge yayılımlarının refah düzeyi düşük ülkelere yönelmesinde olumlu kanıtlar sunmaktadır. Yine Jiang vd. (2010) 1986-2005 yılları arası verileri kullanarak gerçekleştirdiği çalışma, G-7 ülkelerinden yayılan doğrudan bilginin Çin ekonomisi üzerinde pozitif etki oluşturduğunu ve personel akış yoluyla doğrudan bilgi yayılımının Çin'deki uluslararası Ar-Ge yayılmalarının önemli bileşenleri arasında yer aldığını göstermektedir.

Miin Wu örneğinde olduğu gibi bazı çalışmalara göre ise göç eden yüksek vasıflı kişiler ilk süreçte ülkelerine dönme isteği olmasa da ülkelerindeki koşullar iyileşmeye başladığında geri dönebilmektedir. Bu konuyu yakından tartışan Wahba'ya (2014) göre birçok kişi nüfus hareketini tek yönlü bir eylem olarak değerlendirse de çift yönlüdür ve dinamiktir. Ayrıca ona göre yüksek vasıflı göç edenlerin belli bir süre sonra geri döndüğüne dair kanıtlar bulunmakta ve geri dönenlerin sayısında bir artış olduğu tespit edilmektedir. Beyin dolaşımı olarak tarif edilebilen bu gelişme, mali ve beşerî sermayenin kaynak ülkeye transfer etmesi kaynak ülkenin kalkınmasına katkı sağlama açsından bir avantaj sağlamaktadır. Fakat bu katkının ortaya çıkmasının birtakım öncülleri bulunmaktadır. Bu öncüllerin bir kısmı göç edenin bilgi, beceri ve tasarruf konusunda gelişim sağlamışına bağlı olduğu gibi diğerleri kaynak ülkenin bürokrasinin azaltılması, yatırım olanakları hakkında bilgiye sahip olması vb. doğru politik seçeneklerle ilgilidir. Hem bölgesel hem de ulusal düzeyde kısa ve orta vadede beyin dolaşımını daha etkili bir şekilde kolaylaştırma, beyin göçünü azaltacağı ve beşerî sermayeyi yükselteceği varsayılmaktadır (Batalova vd., 2017: 3). 
Parasal girişimlerle birlikte parasal olmayan girişimler de kaynak ülkelerin kalkınması üzerine faaliyet gerçekleştiren kuruluşlar tarafından teşvik edilmektedir. Bu bağlamda geri dönüşlerle birlikte göçmenlerin bilgi ve tecrübelerinin kalkınmada önemli rol oynaması beyin dolaşımı bağlamında konunun tartışılmaya açılmasını teşvik etmektedir (Gökbayrak, 2008: 69). Beyin göçü daha çok hedef ülkenin gelişimine katkı sunduğu beyin dolaşımı sayesinde gerçekleşen yüksek vasıflı göç ise hem hedef ülke hem de kaynak ülkeye fayda sağladığı ön görülmektedir (Saxenian, 2002). Yüksek vasıflı bireylerin küresel hareketliliği beyin göçü kadar olumsuz anlam taşımadığı öngörülmektedir. Beyin dolaşımı sayesinde bireylerin beşerî sermayesinin yükseleceği, yurt dışında oluşturulan ağlar iki veya daha fazla ülke arasındaki iş birliğini teşvik edeceği düşünülmektedir (Kasnauskiene ve Budvytyte, 2013: 740).

Tartışmalar beyin göçünden beyin dolaşımına doğru kayarken bazı çalışmalara göre beyin dolaşımının kaynak ülkenin kalkınmasında önemli rol oynadığına dair yeterli bulgu bulunmamaktadır (Dawson, 2007). Bazı çalışmalar ise beyin dolaşımı teorisinin genel bir durumu ifade etmediğini ve sınırlı bir uygulama alanına sahip olduğunu göstermektedir (Chen, 2008). Yine de beyin göçüne yönelik endişeyle kıyaslatıldığında beyin dolaşımı daha iyimser bir tablo sunduğu görülmektedir (Batalova vd., 2017: ix). Bununla birlikte; küreselleşme, insan hareketliliği önündeki birtakım sınırların kaldırılması, çifte vatandaşlık ve kariyer yapma istediği gibi faktörlere bağı olarak beyin dolaşımının giderek artacağı tahmin edilmektedir (Daugeliene ve Marcinkeviciene, 2009).

\section{Bazı Beyin Dolaşımı Uygulamaları}

Beyin göçünün kalkınma bağlamında özellikle kaynak ülke açısından çeşitli sorunlar meydana getirdiğine yönelik yaygın bir kanaat mevcuttur. Beyin göçünün olumsuz etkilerinin azaltımıyla ilgili tersine beyin göçünün, beyin kazanımının yanında etkin başvurulan temel mekanizmalardan biri beyin sirkülasyonunu ve bilgi dolaşımını sağlamaya yönelik gerçekleştirilen programlardır. Bu tür programlar kapsamında kişiler yurt dışına gönderilirken gönderen ülke açısından sınırlı süreli iş sözleşmelerinin olması hem hizmet sağlayıcıların ve alıcıların hak ve yükümlülüklerini belirlemede hem de göçmenlerin geri dönüşünü ve beyin dolaşımını kolaylaştırmaktadır (Dawson, 2007: 14). Daugeliene ve Marcinkeviciene'ye (2009) göre Hindistan, Kore ve Tayvan gibi bazı Asya ülkeleri beyin göçüne kaynaklık eden ülkelerin başında gelmektedir. Ancak bu ülkeler yakın zamanda beyin dolaşımına yönelik uyguladığı başarılı programlar sayesinde beyin göçünün zararlarının üstesinden gelmeyi başardılar.

Diğer taraftan beyin kazanımı ve beyin dolaşımı için Marie Curie, Erasmus Mundus gibi birçok program hayata geçirilmektedir (Robertson, 2006: 3). Marie Sklodowska Curie Uluslararası Burs ve Araştırma Dolaşım Destekleri "nitelik ve nicelik olarak araştırma ve teknoloji alanındaki insan potansiyelini güçlendirmeyi, araştırmacıların kariyer gelişimini desteklemeyi, uluslararası ve sektörler arası” beşeri sermaye hareketliliğini teşvik eden bir programdır. ${ }^{1}$ Avrupa Birliği tarafından yürütülen Erasmus programı da ülkeler arasında lisans, yüksek lisans, doktora öğrencilerinin dolaşımını mümkün kılarak öğrenim görmesini ve öğretim üyelerinin farklı ülkelerdeki üniversitelerde araştırma yapma olanağı tanımaktadır.

\footnotetext{
${ }^{1}$ https://h2020.org.tr/tr/h2020/marie-curie, Erisim tarihi: 26.08 .2020
} 
Beyin dolaşımı uygulamalarından biri de bazı ülkeler arasında yüksek vasıflı işgücü hareketliliğine yönelik sınırların kaldırılmasına yönelik anlaşmaların hayata geçirilmesidir. Bu programlardan biri vasıflı işgücünün Güneydoğu Asya bölgesindeki sınırların ötesine geçmesini kolaylaştırmak amacıyla Güneydoğu Asya Ülkeleri Birliği'nin (ASEAN) 10 üye devleti arasında bazı mesleklerin hareketliliğine yönelik imzalanan anlaşmadır. Bu anlaşmanın temel hedefi bölge içi vasıflı işgücü hareketliliğini teşvik etmektir. Bu teşvikin temelinde değişen nüfus yapısı, yükselen eğitim seviyesi ve arzusu, ekonomik talepler yer almaktadır (Batalova vd., 2017: vii). Türkiye'de de beyin dolaşımına yönelik birçok program hayata geçirilmektedir. Bu programları düzenleyen aktörlerden biri de TÜBіTAK'tır. Bu kapsamda Türkiye'de TÜBіTAK etkin rol alarak çeşitli atölyeler ve programlar düzenlemektedir. "Research Destination Turkey" çalışması bunlardan biridir (Arslan, 2016: 155).

\section{SONUÇ ve TARTIŞMA}

Çeşitli çalışmalarda elde edilen bulgular göçün kalkınma üzerinde pozitif bir etki oluşturduğunu gösterse de bazı çalışmalar özellikle beyin göçünün kaynak ülkenin ekonomisi üzerinde negatif bir etki oluşturduğunu belirtmektedir (Le, 2008: 618). Dahası yüksek vasıfı kişilerin göçü bir ülke için tehdit olarak kabul edilmektedir (Kasnauskienè ve Budvytyte, 2013). Diğer bazı çalışmalar ise esas olarak daimî göç yerine döngüsel göçün kalkınma üzerinde daha belirleyici olduğunu ortaya koymaktadır. Ayrıca göçün kalkınmayı pozitif yönde etkilediğini düşünen bakış açısına göre göçmenler ülkelerine geri döndüklerinde bilgi ve becerilerini ülkesine transfer ederek kalkınma üzerinde belirleyici olmaktadır (Aktaş, 2015: 38). Başka ülkelere göçle birlikte daha yüksek ücret alma düşüncesi beşerî sermaye birikimine katkı sağlayarak kaynak ülkenin ekonomik gelişimini etkilemektedir. Bu vesileyle beşerî sermaye birikiminde göçün etkili olduğu düşünülmektedir (Drinkwater vd., 2003: 18).

Kalkınma açısından göçe pozitif bir anlam yükleyen düşünce göçmenlerin beşerî sermayesini ülkelerine transfer ederek beyin dolaşımını meydana getireceğini ön görmektedir (Aktaş, 2015). Küreselleşme, çifte vatandaşlık, insan hareketliği önündeki engellerin azalması gibi dinamikler çift yönlü nüfus hareketliliğini teşvik etmektedir (Daugeliene ve Marcinkeviciene, 2009). Giderek daha fazla insan yurt dışında çalışmak veya öğrenim görmek amacıyla göç eğilimi sergilerken Kasnauskienè ve Budvytyte'ye göre beyin göçü yerine giderek beyin dolaşımı daha sık kullanılan bir kavram haline gelmekte ve beyin dolaşımının kaynak ülkeye daha fazla fayda sunacağı tahmin edilmektedir. Çünkü yurt dışında kurulan ağ ve sağlanan deneyim geri dönüşlerde bölgenin kalkınmasında etkili olmaktadır (Kasnauskienė ve Budvytyte, 2013). Yüksek vasıflı işgücünün hareketliliği ve bilginin transferine karşılık gelen beyin dolaşımı kalkınma açısından daha fazla kabul görmektedir. Kişinin yurt dışında edinmiş olduğu bilgi ve becerisini ülkesine döndüğünde uygulama fırsatına sahip olması kalkınmayı olumlu yönde etkileyeceği tahmin edilmektedir (Beine, Docquier ve Rapoport, 2008). Beyin dolaşımıyla birlikte beceri, sermaye ve teknolojinin çift yönlü akışı olanaklı hale gelmektedir. Sonuç olarak daha iyi bir yaşam için ülkesini terk eden beşeri sermaye düzeyi yüksek kişiler beyin göçünü tersine çevirerek beyin dolaşımına dönüştürmektedir (Zhang, 2013). Ancak bazı çalışmalara göre göçmenlerin ülkelerine geri dönmesi her zaman ülkenin kalkınmasına pozitif katkı sunacağı anlamına gelmektedir. Geri dönen göçmenlerin becerileri ile istihdam arasındaki uyumluluk, kaynak ülkenin sosyal, kültürel ve kurumsal bağlamı da etkili olmaktadır 
(Velema, 2012). Ayrıca göç-kalkınma ilişkisi beyin dolaşımı bağlamında daha somut veriler üzerinden geniş bir açıdan irdelenebilir. Bununla birlikte uluslararası göç dünyadaki gündemini korudukça beyin dolaşımı boyutunun da tartışılmaya devam edeceği düşünülmektedir.

\section{ETIK METNi}

"Bu yazıda dergide belirtilen yazım kuralları, araştırma ve yayın etiği, yayın ilkeleri ve etik kurallara uyulmuştur. Bu makaleden kaynaklanan tüm ihlaller yazarın sorumluluğundadır."

\section{KAYNAKÇA}

Aktaş, M. T. (2015). Göç olgusu ekonomik kalkınmada itici güç olabilir mi?. Aksaray Üniversitesi Iktisadi ve Idari Bilimler Fakültesi Dergisi, 7(1), 37-48.

Arslan, N. (2016). Beyin Göçü ve Kalkınma: Türkiye'nin Kalkınmasında Türk Bilim Diaspora Ağlarının Rolü. Yayınlanmamış Doktora Tezi, İstanbul Üniversitesi Sosyal Bilimler Enstitüsü, İstanbul.

Batalova, J., Shymonyak, A., and Sugiyarto, G. (2017). Firing Up Regional Brain Networks: The Promise of Brain Circulation in the ASEAN Economic Community. Asian Development Bank.

Beine, M., Docquier, F. ve Rapoport, H. (2008). Brain drain and human capital formation in developing countries: winners and losers. The Economic Journal, 118(528), 631-652.

Chen, Y. C. (2008). The limits of brain circulation: Chinese returnees and technological development in Beijing. Pacific Affairs, 81(2), 195-215.

Daugeliene, R., ve Marcinkeviciene, R. (2009). Brain circulation: theoretical considerations. Engineering economics, 63(4), 49-57.

Dawson, L.R. (2008). Brain drain, brain circulation, remittances and development: Prospects for the Caribbean. Centre for International Governance Innovation. http://www.cigionline.org/publications/2007/6/brain-drain-brain-circulationremittances and-development-prospects-caribbean

Dodani, S. ve LaPorte, R. E. (2005). Brain drain from developing countries: how can brain drain be converted into wisdom gain?. Journal of the Royal Society of Medicine, 98(11), 487-491.

Drinkwater, S., Levine, P., Lotti, E. ve Pearlman, J. (2003). The economic impact of migration: A survey. Hamburgisches Welt-Wirtschafts-Archiv.

Friesen, W. (2014) Diaspora, Brain Circulation and Indian Development. In: Sahoo S., Pattanaik B. (eds) Global Diasporas and Development. Springer, Yeni Delhi. https://doi.org/10.1007/978-81-322-1047-4_8

Gökbayrak, Ş. (2008). Uluslararası göç ve kalkınma tartışmaları: Beyin göçü üzerine bir inceleme. Ankara Üniversitesi SBF Dergisi, 63(3), 65-82.

İnce, C. (2015). "Beşerî Sermaye ve Ekonomik Kalkınma Arasındaki İlişkinin Sosyolojik Analizi." IV. Arap-Türk Sosyal Bilimler Kongresi (ss. 177-193), SDE Yayınları.

Jiang, R., Cai, H., Li, Y., \& Li, H. (2010). China's sustained economic growth: Do direct R\&D spillovers matter?. China \& World Economy, 18(5), 37-53.

Kana, M. A. (2009). From brain drain to brain circulation. Jos Journal of Medicine, 4(1), 8-10. 
Kasnauskiene, G. ve Budvytyte, A. (2013). Economic Challenges of Brain Circulation: The Small Country Case. Mediterranean Journal of Social Sciences, 4(9), 740-747.

Kone, Z. L. ve Özden, Ç. (2017). Brain drain, gain and circulation. Knomad Workıng Paper 19. https://www.knomad.org/sites/default/files/2017-

04/KNOMAD\%20WP19_Brain\%20Drain\%20gain\%20and\%20circulation.pdf

Le, T. (2008). 'Brain Drain'or 'Brain Circulation': Evidence From OECD's International Migration and R\&D Spillovers. Scottish Journal of Political Economy, 55(5), 618-636.

Le, T. (2010). Are student flows a significant channel of R\&D spillovers from the north to the south? Economics Letters, 107(3), 315-317.

Pazarcık, S. F. (2010). Beyin Göçü Olgusu ve Amerika Birleşik Devletleri Üniversitelerinde Çalışan Türk Sosyal Bilimciler Üzerine Bir Araştırma. Yayınlanmamış Yüksek Lisans Tezi, Çanakkale Onsekiz Mart Üniversitesi Sosyal Bilimler Enstitüsü, Çanakkale.

Rosenzweig, M. R. (2008). Higher education and international migration in Asia: Brain circulation. In Annual World Bank conference on development economics (ss. 59-100). World Bank.

Sağırlı, M. (2006). Eğitim ve Insan Kaynağı Yönünden Türk Beyin Göçü: Geri Dönen Türk Akademisyenler Üzerine Alan Araştırması. Yayınlanmamış Doktora Tezi, İstanbul Üniversitesi, Sosyal Bilimler Enstitüsü, İstanbul.

Saxenian, A. (2002). Brain circulation. How high-skill immigration makes everyone better off. Brookings Review, 20(1), 28-31.

Shin, G. W. ve Moon, R. J. (2018). From Brain Drain to Brain Circulation and Linkage. Shorenstein Asia Pacific Research Center Working Paper. Stanford, CA: Stanford University. https://fsi.stanford.edu/publication/brain-drain-brain-circulation-and-linkage

Susan L. Robertson (2006) Brain drain, brain gain and brain circulation. Globalisation, Societies and Education, 4(1), 1-5. 10.1080/14767720600554908

Velema, T. A. (2012). The contingent nature of brain gain and brain circulation: their foreign context and the impact of return scientists on the scientific community in their country of origin. Scientometrics, 93(3), 893-913.

Wahba, J. (2014). Who benefits from return migration to developing countries?. IZA World of Labor, February, 123. 10.15185/izawol.123

Winters, L. A. (2008). Skilled labor and the international economy: Whence it comes, whither it goes. In Annual World Bank conference on development economics (ss. 15-24). World Bank.

Zhang, W. (2013). Reaping the benefits of brain circulation: the impact of the overseas study and the returnees on the development of the management education in China. In Innovation in Business Education in Emerging Markets (ss. 208-221). Palgrave Macmillan, London. 